\title{
Jim Cummins
}

The University of Toronto, Canada

\section{SHOULD SCHOOLS UNDERMINE OR SUSTAIN MULTILINGUALISM? AN ANALYSIS OF THEORY, RESEARCH, AND PEDAGOGICAL PRACTICE}

Summary. Most school systems around the world prioritize the teaching of languages and aim to develop bilingual or multilingual proficiencies among their students. However, in a large number of contexts, schools also systematically and intentionally undermine the potential of immigrant-background and minoritized students to develop multilingual abilities. This undermining of multilingualism operates either by explicitly prohibiting students from using their home languages (L1) within the school or through ignoring the languages that students bring to school (benign neglect). In some cases, exclusion of students' L1 is rationalized on the grounds that maintenance of L1 will hinder students' integration into the mainstream society. In other cases, exclusion is based on the conviction that there is competition between languages and use of the L1 either in school or home will reduce students' exposure to the school language (L2). The validity of this time-on-task argument is critically analyzed in the present paper. I argue that the research shows no consistent relationship between immigrant students' academic achievement (in L2) and use of L1 in the home or in the school. By contrast, several research syntheses have highlighted the positive academic outcomes of bilingual programs for minoritized students and also the feasibility of implementing multilingual or translanguaging pedagogies in the mainstream classroom.

Keywords: bilingual education; cross-lingual transfer; home language; immigrantbackground students; interdependence; multilingualism; time-on-task; translanguaging.

\section{Introduction}

The most likely reaction of many readers to the question posed in the title of this paper is that of course schools should promote and sustain multilingualism among students. Clearly, most schools around the world do teach languages and attempt to promote bilingual and/or multilingual abilities with varying degrees of success. However, a large number of schools around the world also systematically and intentionally undermine students' potential to develop multilingual abilities. This apparent paradox derives from the fact that schools, and the societies that fund them, view the learning of languages as an important goal for 'mainstream' student populations, but they frequently regard the maintenance and development of the home languages of immigrant-background and minoritized students as counterproductive. 
Arguments against maintenance of home languages fall into two broad and overlapping categories: (1) continuing use of the home language by school-age students will delay or even block students' integration into the mainstream society; (2) continuing use of the home language will impede students' learning of the school language and their overall academic achievement.

In this paper, I examine the empirical and theoretical legitimacy of these claims. Three criteria for assessing the credibility of any theoretical proposition are articulated and, on the basis of these criteria, I argue that the empirical and theoretical justifications advanced by policymakers and some researchers for undermining students' multilingualism are without foundation. Furthermore, the monolingual instructional approaches that are rationalized by these theoretical and empirical claims are less effective in promoting academic achievement among immigrant-background students than approaches that attempt to promote biliteracy in students' home language and in the major school language. Instructional innovations implemented by educators in many contexts during the past 20 years have demonstrated the feasibility of harnessing multilingual students' home languages as pedagogical resources within the classroom. The essential components of these pedagogical approaches will be described to illustrate the outcomes of teaching for crosslingual transfer, and the theoretical and empirical foundations for sustaining multilingualism in linguistically diverse classrooms will be discussed.

\section{Undermining Multilingualism}

\section{Active Suppression of Students' Languages}

Historically, the languages of minoritized groups have often been actively suppressed for ideological reasons rooted in racism and nativism. This process is most clearly illustrated in the 'cultural genocide,' which Indigenous children experienced in residential schools that operated in countries such as Canada, the United States, and Australia for more than 150 years. These schools were explicitly designed to eradicate Indigenous languages and destroy children's Indigenous identities. (Truth and Reconciliation Commission of Canada, 2015). 
More recently, in many contexts, immigrant-background students' home languages (L1) have been viewed by policymakers and educators as an impediment to learning the school language and teachers have actively discouraged students from using their languages in school. In some cases, students have been physically punished for using their languages and parents have been advised to refrain from using their home language in interaction with their children. For example, Agirdag (2010) reported that Turkishbackground secondary school students in the Flemish-speaking regions of Belgium were strongly discouraged from speaking Turkish in school:

\begin{abstract}
Our data show that Dutch monolingualism is strongly imposed in three different ways: teachers and school staff strongly encourage the exclusive use of Dutch, bilingual students are formally punished for speaking their mother tongue, and their home languages are excluded from the cultural repertoire of the school. At the same time, prestigious languages such as English and French are highly valued (p. 317).
\end{abstract}

A more recent study carried out by Pulinx, Van Avermaet, and Agirdag (2016) found that 77 percent of Flemish teachers believed that immigrant-background students should not be permitted to speak their home languages at school, and almost a third of teachers agreed that students should be punished for transgressing this rule. Pulinx and colleagues point out that these teachers are well-intentioned. They believe that immigrant-background students require maximum exposure to and encouragement to use the school language. In light of this assumption, it is not surprising that they view students' use of L1 in the school as counterproductive.

\title{
Benign Neglect of Students' Languages
}

A more common contemporary orientation to immigrant-background students' multilingualism in many contexts (e.g., Canada, Australia) is 'benign neglect'. Students' home languages are no longer seen as an impediment to learning of the school language but the diversity of languages in typical schools means that teachers see no way to promote them within the mainstream classroom. Maintenance of home languages is typically seen as an issue for the parents 
rather than the school, and implicit monolingual policies continued to operate in schools.

The rapidity with which primary school students internalize the monolingual norms of the school can be illustrated in the experience of a grade 1 student in a school near Toronto, Canada, who felt embarrassed to use her home language Cantonese in calling her grandmother from the school office. The student reflected on this experience when she was in grade 5 after her teacher had opened up discussion of multilingualism within her class, sharing with her students the numerous languages she had learned growing up in India and asking students to reflect on and write about the languages they knew. The school was highly multilingual, but up to that point, very little explicit attention had been paid to students' languages.

I am not always comfortable speaking Cantonese when I have to go to the office for some reason. I don't like it because a lot of teachers are at the office and I don't like speaking it in front of them. I know that they are listening to me. I get nervous and afraid. For example, once I didn't feel very well in grade 1 . So, my teacher sent me to the office to call my grandma. My grandma doesn't speak English and she also can't hear very well, so I had to speak in Cantonese very loudly for her to hear. So, when I spoke to my grandma, I felt very nervous.

In this example, the student clearly would not have been reprimanded for speaking Cantonese in calling home. However, by the age of 6 , she had already internalized the conviction that English was the only legitimate language within the school. The fact that she still remembered this experience four years later highlights just how much it affected her emotionally at the time.

Despite the fact that monolingual approaches continue to predominate in teaching immigrant-background students, only a handful of researchers have actively advocated such approaches. Fewer still have advanced a coherent theoretical rationale for undermining students' knowledge of their L1 and their potential to develop active multilingual abilities. The theoretical and empirical claims that have been made are reviewed in the next section. 


\section{Theoretical and Empirical Arguments for Undermining Multilingualism}

As noted previously, arguments against L1 maintenance among minoritized and immigrant-background students invoke one or both of the following claims: (a) L1 maintenance will delay integration into mainstream society; (b) L1 maintenance will impede learning of the school language. Both of these arguments have been prominent during the debates about bilingual education for minority group students in the United States over the past 40 years (since the mid-1970s). The first argument was never supported by empirical data it was simply asserted as self-evident fact, as exemplified in the following passage from eminent historian Arthur Schlesinger Jr.'s (1991) book The Disuniting of America:

In recent years the combination of the ethnicity cult with a flood of immigration from Spanish-speaking countries has given bilingualism new impetus. ... Alas, bilingualism has not worked out as planned: rather the contrary. Testimony is mixed, but indications are that bilingual education retards rather than expedites the movement of Hispanic children into the English-speaking world and that it promotes segregation rather than it does integration. Bilingualism shuts doors. It nourishes self-ghettoization, and ghettoization nourishes racial antagonism (p. 108).

Schlesinger goes on to assert that monolingual English-only education is required to give minoritized students the opportunity to learn English and succeed in the society: "Using some language other than English dooms people to second-class citizenship in American society. ... Monolingual education opens doors to the larger world" (1991, p. 109).

The argument that "bilingualism shuts doors" is clearly absurd but a number of other commentators have made the superficially more credible claim that 'time on task' is the major variable determining attainment in any school subject and thus minority group students should experience maximum exposure to the school language in order to learn it rapidly and effectively. In the United States context, Rosalie Pedalino Porter in her book Forked Tongue: The Politics of Bilingual Education made the case for time on task as follows: 
Effective time on task - the amount of time spent learning-is, as educators know, the single greatest predictor of educational achievement; this is at least as true, if not more so, for lowsocioeconomic-level, limited-English students. Children learn what they are taught, and if they are taught mainly in Spanish for several years, their Spanish-language skills will be far better than their English-language ones (1990, pp. 63-64).

Similar arguments have been made by Rossell and Baker (1996) and Rossell and Kuder (2005). The research reviews conducted by these authors claim to demonstrate that 'structured immersion' programs (i.e., monolingual Englishmedium programs) are superior in their outcomes to bilingual programs that use students' L1 as a medium of instruction in addition to English. These literature reviews have been strongly criticized on multiple grounds. For example, Cummins (1999) argued that the Rossell and Baker (1996) review is "characterized by inaccurate and arbitrary labeling of programs, inconsistent application of criteria for 'methodological acceptability,' and highly inaccurate interpretation of the results of early French immersion programs". The credibility of their review can be gauged from the fact that $90 \%$ of the studies they claimed as support for English-medium 'structured immersion' are interpreted by the authors of these studies as supporting the effectiveness of bilingual and even trilingual education.

A more coherent empirical case for the negative effects of students' home languages on the learning of the school language has been made by several authors on the basis of the results of the Programme for International Student Assessment (PISA) carried out since the year 2000 by the Organisation for Economic Cooperation and Development (OECD). Successive PISA studies have reported a negative relationship between academic achievement and use of a language other than the school language at home (e.g., Christensen \& Stanat, 2007; Nusche, 2008; OECD, 2012; Stanat \& Christensen, 2006). The PISA research showed that in both mathematics and reading, first- and second-generation immigrant-background students who spoke their L1 at home were significantly behind their peers who spoke the school language at home. Christensen and Stanat (2007) concluded: "These large differences in performance suggest that students have insufficient opportunities to learn the language of instruction" (p. 3). German sociologist Hartmut Esser (2006) similarly concluded on the basis of PISA data that "the use of the native 
language in the family context has a (clearly) negative effect" (p. 64). He further argued that retention of the home language by immigrant children will reduce both motivation and success in learning the host country language (2006, p. 34). These researchers argue for immersing immigrant-background children in the societal language from age 3, thereby increasing opportunities to learn that language (and, by the same token, reducing exposure to L1 and its associated 'negative effects'). Consistent with this position, both Stanat and Christensen, and Esser, claim that there is little evidence that bilingual education is a credible option for increasing immigrant-background students' academic achievement.

Other research studies have also claimed a time-on-task effect in relation to the language spoken by immigrant-background students in the home. For example, Scheele, Leseman, \& Mayo (2010) in a study of 3year-old children in the Netherlands from Dutch, Moroccan-Dutch, and TurkishDutch home backgrounds found a significant relationship between the amount of language-specific literate and oral input in the home and children's development of both $L 1$ and $L 2$ language skills. They interpret this finding as indicating competition between L1 and L2 input. However, they also reported significant positive cross-language transfer from L1 to L2, which they suggest is capable of partially mitigating the negative association between L1 input and Dutch language development.

Edele and Stanat (2016) carried out a large-scale and well-designed study of Russian- and Turkish-speaking $9^{\text {th }}$ grade students (aged approximately 15 years) in Germany focused primarily on investigating the relationship between L1 listening comprehension and German (L2) reading comprehension skills. For both groups, they reported significant relationships between $\mathrm{L} 1$ listening comprehension and $\mathrm{L} 2$ reading comprehension that were independent of background variables such as SES, non-verbal cognitive ability, and type of school. Of interest in the present context, however, is their finding that "frequent use of L1 in the family is negatively associated with students' L2 reading comprehension" (p. 174). They interpret this finding as evidence for a competing relationship between the learning time for L1 and L2 as suggested by the time-on-task argument: "According to this argument, the frequent use of L1 in the family has negative effects on the proficiency level 
that a student will reach in L2 because it limits the learning time available for the acquisition of L2" (p. 174).

\title{
Critique of Arguments for Monolingual Instruction in the School Language
}

\section{Criteria for Evaluating Theoretical Claims or Constructs}

Three criteria can be invoked for judging the credibility of any theoretical claim relating to education: (a) adequacy - to what extent is the claim consistent with all the relevant empirical evidence? (b) logical coherence - to what extent is the claim internally consistent and non-contradictory? (c) consequential validity - to what extent is the claim useful in promoting effective pedagogy? Cummins (2009) expressed this perspective as follows:

\begin{abstract}
Theoretical claims or frameworks that integrate these claims are not valid or invalid, true or false; rather, they should be judged by criteria of adequacy and usefulness. Adequacy refers to the extent to which the claims or categories embedded in the framework are consistent with the empirical data and provide a coherent and comprehensive account of the data. Usefulness refers to the extent to which the framework can be used effectively by its intended audience to implement the educational policies and practices it implies or prescribes (p. 4).
\end{abstract}

There is general agreement that theoretical claims must be consistent with the empirical data. If a claim or proposition is inconsistent with credible empirical data, it must be modified or qualified to account for the data.

The role of logical coherence in evaluating the credibility of a theoretical claim can be illustrated in Flores and Rosa's (2015) assertion that additive approaches to language education (e.g., promotion of biliteracy among minoritized students) are infused with raciolinguistic ideologies and discourses of appropriateness that are "complicit in normalizing the reproduction of the white gaze by marginalizing the linguistic practices of language-minoritized populations in U.S. society" (p. 166). This counterintuitive claim is based on the fact that Flores and Rosa identify the promotion of 'literacy' (and biliteracy) with the promotion of 'standardized language', which automatically excludes 
and disadvantages the non-standard linguistic practices of minoritized communities.

Flores and Rosa's (2015) position has been challenged by Cummins (2017) on the grounds that there is no empirical or theoretical basis for conflating additive bilingualism and biliteracy with 'standardized language skills'. If that were the case, all attempts to develop literacy skills (in L1 and/or L2) among minoritized students would be racist. The logical contradictions in Flores and Rosa's (2015) arguments are also evident in their assertion that they are "not suggesting that advocates of additive approaches to language education should abandon all of their efforts to legitimize the linguistic practices of their language-minoritized students" (p. 167). Does this mean that teachers should abandon only some of their efforts to promote additive bilingualism? If so, which instructional components are problematic, and which are acceptable? The logical contradiction in Flores and Rosa's rejection of additive approaches to bilingualism lies in the authors' (implicit) suggestion that teachers who encourage their students to pursue biliteracy (additive bilingualism) are "complicit in normalizing the reproduction of the white gaze" (p. 166), but at the same time these teachers, according to Flores and Rosa, should continue to legitimize the linguistic practices of their students by, presumably, promoting biliteracy skills in students' home languages and English.

The notion of consequential validity was initially articulated in the area of educational testing by Messick (1987) who argued that discussions of the validity of any assessment procedure or test should take into account the social consequences of using this procedure in educational contexts. For example, research (reviewed by Ravitch, 2013) has documented that extensive use of high-stakes standardized testing during the era of the No Child Left Behind legislation in the United States (2002-2015) resulted in a narrowing of the curriculum to focus only on content that would be assessed in the test. This, in turn, gave rise to a 'pedagogical divide' whereby low-income students who were at risk of failing the tests experienced a significant increase in drilland-practice test-preparation instruction in comparison to more affluent students who were less likely to be considered at risk of failure (Cummins, 2007). Extrapolating the notion of consequential validity to the broader sphere of theoretical claims implies that such claims should be subjected to 
a classroom 'reality check' to assess the credibility of their instructional implications.

An example of how the notion of consequential validity can be applied to theoretical constructs comes from the conceptualization of 'translanguaging' advanced by García and Wei (2014). These authors argue that because languages do not exist as discrete entities within our minds, our linguistic system is unitary and undifferentiated with features that are totally integrated rather than being associated with any particular language. Based on this conceptualization, they critique scholars "who still speak about L1, L2 and code-switching" (p. 62). They also argue that we can now "shed the concept of transfer... [in favor of] a conceptualization of integration of language practices in the person of the learner" (emphasis original) (p. 80). The argument that individual languages don't exist as discrete entities and that teaching for transfer across languages is consequently an illegitimate pedagogical practice immediately fails the classroom reality check. If not teaching for transfer, how should teachers in a Spanish/English bilingual program conceptualize what they are doing when they draw students' attention to similarities between encontrar and encounter?

\section{Evaluating the Time-on-task Argument against Bilingual Education}

If the time-on-task claim were valid, we would expect to see major differences between minority group students educated bilingually and those educated only through the major school language (e.g., English in the United States) for the simple reason that students educated bilingually typically experience at least $50 \%$ less instructional time through the major school language than similar students educated monolingually in that language. Instead, multiple reviews of the evaluation research carried out over the past 30 years (e.g., Cummins, 2001; Francis, Lesaux \& August, 2006) are consistent with the following conclusion articulated by the National Academies of Sciences, Engineering, and Medicine (2017):

Conclusion 7-1: Syntheses of evaluation studies that compare outcomes for ELs [English learners] instructed in English-only 
programs with outcomes for ELs instructed bilingually find either that there is no difference in outcomes measured in English or that ELs in bilingual programs outperform ELS instructed only in English. Two recent studies that followed students for sufficient time to gauge longer-term effects of language of instruction on EL outcomes find benefits for bilingual compared with English-only approaches (p. 7-23).

In other words, the claim that monolingual education in the majority school language will produce superior outcomes compared to bilingual education that promotes biliteracy in both L1 and L2 is inconsistent with the research and fails the test of empirical adequacy.

These arguments also fail the test of logical coherence. As just one example, Porter (1990) argued strongly against transitional bilingual education on the grounds that it failed to teach children English effectively and violated the 'time-on-task' principle that posited a direct relationship between time spent through the medium of English and English achievement. However, she goes on to strongly endorse two-way bilingual programs for both linguistic majority and minority students which, she asserts, "are also considered to be the best possible vehicles for integration of language minority students, since these students are grouped with English-speakers for natural and equal exchange of skills" (p. 154). She seems oblivious to the fact that typical twoway or dual language programs involve considerably more instruction through the minority language than is the case with short-term transitional bilingual programs and thus linguistic minority students will spend even less time "ontask" in two-way bilingual than in transitional bilingual programs.

\section{Evaluating the Claim that L1 Use in the Home Impedes L2 Learning in School}

As noted previously, several OECD reports have attributed the performance gap associated with home L1 use to the fact that use of the L1 in the home limits students' exposure to the dominant school language. For example, an OECD (2012) report entitled Untapped Skills: Realising the Potential of Immigrant Students summarized this interpretation of the data as follows: 
PISA results suggest that students who mostly speak a different language at home from that which is used in school have significantly lower reading scores than those who tend to use the test language at home most of the time. This effect is very strong, accounting for a difference of about 30 points in reading scores, on average, between those who mostly speak the test language at home and those who do not... The language skills of parents, particularly of mothers, may not be sufficient to allow them to assist their children in their schoolwork. The objective needs to be more exposure to the host-country language, both in and out of school (pp. 12-14).

Cummins (2018) critiqued this interpretation of the research data on multiple grounds including (a) the crudeness of the dichotomous home language index used in early PISA studies; (b) the claim that home use of L1 automatically translates into 'insufficient exposure' to the school language; (c) the fact that the relationship between achievement and L1 use at home is a relationship of association, not causation; (d) failure to consider alternative directions of possible causal relations, namely that success in learning the school language might lead to greater use of that language in the home rather than the opposite relationship; (e) failure to account for the findings of many other research studies that contradict the proposition that L1 use at home causes underachievement; ( $f$ ) failure to acknowledge PISA findings that show no relationship between home L1 use and achievement in a majority of OECD countries when socioeconomic status [SES] and other background variables were controlled; $(g)$ the outcomes of bilingual education programs, which refute the 'time-on-task' or 'maximum exposure' hypothesis underlying the 'insufficient exposure' claim.

Agirdag and Vanlaar (2016) have also refuted the claim that L1 use at home by immigrant-background students impedes L2 learning and school achievement by analyzing more recent (2012) PISA data that included detailed questions on home language use rather than the dichotomous question on language use at home included in early PISA research. As in previous PISA studies, they reported an achievement gap between immigrant-background and native-speaking students in both reading and mathematics in a large majority of countries. The achievement gap narrowed but remained significant after students' background characteristics (e.g., SES) were taken into account. However, Agirdag and Vanlaar also reported that immigrant-background students who spoke their home language more often with their parents 
performed as well as those who spoke the dominant societal language with their parents. They found that in most countries, home language use is unrelated to academic performance but in some countries, such as Canada, Finland, and Singapore, speaking a minority language with parents was positively related to achievement in the dominant language.

The finding in the Scheele et al. (2010) study of a negative relationship between L1 use in the home and Dutch language development is not at all surprising in light of the fact that participants in the research were 3-year-old children. In the very early stages of language development, the amount of input in any particular language is likely to determine proficiency at that point in time. However, as children are exposed to extensive L2 input in the primary school, the effect of L1 home language input on L2 development disappears, as demonstrated in the Agirdag and Vanlaar (2016) research.

Edele and Stanat's (2016) interpretation of their findings as supporting the time-on-task hypothesis is subject to many of the same critiques as those discussed in relation to the OECD PISA studies (Cummins, 2018). Although some important background variables (e.g., SES and non-verbal cognitive ability) were controlled, no data were available for length of residence in Germany. In comparison to students born in Germany or those who arrived at an early age, recently arrived students who are still in the process of acquiring German are more likely to use L1 at home and also to perform more poorly on measures of German proficiency. Consider, for example, the situation of a grade 7 immigrant student who arrives in Germany at age 13; this student is likely to perform poorly on measures of German proficiency at age 15 and also to continue using L1 at home with his/her parents who may know very little German. Thus, the direction of causality (if causality exists) is unclear; students who arrive at an early age or who are faster at learning German are more likely to switch from L1 to German in the home. Furthermore, interpretation of the correlational data between L1 use at home and underachievement in terms of time-on-task would also have to account for the fact that this hypothesis has been refuted by the many research studies that show either no relationship or an inverse relationship between school achievement and language spoken at home (Cummins, 2018).

In conclusion, there is no empirical justification for constructing immigrant students' home language as a cause of underachievement nor for 
promoting L2 immersion as a preferred instructional option. Instead, the data suggest that parents should be encouraged to continue using their home language with their children in order to provide them with a strong conceptual basis for acquiring the school language and developing active bilingualism and biliteracy.

\section{Theoretical and Empirical Arguments for Sustaining Multilingualism}

The ideological foundation for adopting policies and pedagogical practices that sustain students' multilingualism can be simply stated: It is the right of all students to have their talents and abilities recognized and promoted by educators within the school. These talents and abilities include the languages that students bring to school that enable them to communicate with parents, siblings, and other family members. Students' cultural and linguistic experience in the home is the foundation of their future learning and educators who aspire to promote students' abilities must build on that foundation rather than undermine it.

To what extent are the pedagogical implications of this ideological foundation consistent with theory and research relating to educating immigrant-background multilingual students? To what extent is it feasible for schools to sustain students' multilingualism in contexts where linguistic diversity is the norm and many languages may exit within schools and classrooms?

\section{Linguistic Interdependence in Bilingual and Multilingual Students}

As noted previously, there is an abundance of research showing that students in bilingual programs perform at least as well in majority language literacy skills compared to similar students in monolingual programs who have had much more instructional exposure to the majority language. Research has also consistently reported significant cross-lingual relationships even between linguistically dissimilar languages (e.g., Edele \& Stanat, 2016). In order to 
account for these research results, Cummins (1979, 1981) proposed the 'interdependence hypothesis' which was formally expressed in the following way:

To the extent that instruction in $L x$ is effective in promoting proficiency in Lx, transfer of this proficiency to Ly will occur provided there is adequate exposure to Ly (either in school or environment) and adequate motivation to learn Ly (1981, p. 29).

In concrete terms, what this hypothesis means is that in, for example, a Spanish-English bilingual program in the United States, instruction that develops speaking, listening, reading and writing skills in Spanish is not just developing Spanish skills, it is also developing a deeper conceptual and linguistic proficiency that is strongly related to the development of literacy in the dominant language (English). In other words, although the surface aspects (e.g., pronunciation, fluency, etc.) of different languages are clearly separate, there is an underlying conceptual proficiency, or knowledge base, that is common across languages. This common underlying proficiency makes possible the transfer of concepts, literacy skills, and learning strategies from one language to another. The transfer of skills, strategies, and knowledge explains why spending instructional time through a minority or non-dominant language entails no adverse consequences for the development of academic skills in the dominant language.

Although the basic concept is the same, different researchers have proposed alternative terms to refer to the notion of a common underlying proficiency (CUP). Baker (2001), for example, discussed the common operating system, Kecskes and Papp (2000) proposed a common underlying conceptual base, while Genesee et al. (2006) labeled the phenomenon a common underlying reservoir of literacy abilities. The empirical basis for crosslinguistic interdependence was reinforced by the conclusions of the research synthesis written by the National Academies of Sciences, Engineering, and Medicine (2017):

Conclusion 6-3: The languages of bilinguals do not develop in isolation from one another. Evidence indicates that certain aspects of dual language learning, processing, and usage are significantly and positively correlated and that the development of strong L1 skills supports the development 
of English-L2 skills. This interrelationship has been shown to be most evident in domains related to the acquisition of literacy skills and in languages that are typologically similar.

Conclusion 6-4: Evidence reveals significant positive correlations between literacy skills in ELs' $L 1$ and the development of literacy skills in English-L2. Educational programs that provide systematic support for the development of ELs' L1 often facilitate and enhance their development of skills in English, especially literacy (p. 6-23).

In short, the interdependence hypothesis and the notion of a common underlying proficiency provide an empirically supported and theoretically coherent foundation for both bilingual education and teaching for cross-lingual transfer. From the perspective of consequential validity, these constructs legitimate instructional use of immigrant-background students' L1 and also call into question the pedagogical basis of monolingual instructional approaches that minimize the possibility of two-way transfer across languages. These constructs are also fully consistent with more recent and more detailed theoretical formulations of multilingual functioning such as multicompetence (Cook, 1995, 2007), dynamic systems theories of bilingualism (e.g., Herdina \& Jessner, 2002), and translanguaging (e.g., García, 2009). What all these constructs share is a recognition that the languages of bi- and multilinguals interact in complex ways that can enhance aspects of overall language and literacy development.

\section{Pedagogical Practices that Sustain Multilingualism}

Clearly, with the exception of quick-exit transitional bilingual programs for minority group students, most bilingual programs are intended to develop strong bilingual and biliteracy skills. However, bilingual programs for minority group students require a concentration of students from the same linguistic backgrounds in order to make implementation feasible. In educational contexts with students from highly diverse linguistic backgrounds, bilingual programs are typically not feasible. However, during the past 20 or so years, educators have also begun to explore multilingual instructional strategies for teaching immigrant-background students in 'mainstream' classrooms. The goal is to bring home and school languages into productive contact with the goal of 
affirming and developing both (Auger, 2008; Celic \& Seltzer, 2011; ChumakHorbatsch, 2012, 2019; Cummins \& Early, 2011; DeFazio, 1997; García, \& Kleyn, 2016; Hélot \& Young, 2006; Kapoyannis, 2019; Little \& Kirwan, 2018, 2019; Mary \& Young, 2017; Pickel \& Hélot, 2014; Prasad, 2016). Two examples from this growing body of research will illustrate emerging trends in multilingual pedagogy.

DeFazio (1997). The International High School at LaGuardia Community College. The International High School (IHS) in La Guardia Community College, New York City, was founded in 1985 and offers secondary school learners of English a four-year comprehensive program where they can satisfy state mandated subject matter requirements while they are learning English (DeFazio, 1997; DevTech Systems, 1996). The students come from over 60 countries and speak more than 50 different languages. The IHS school web site outlines the current philosophy and program at IHS as follows:

IHS offers a rigorous college preparatory program for limited English proficient students in a multicultural educational environment. IHS gives priority to students of limited English proficiency who have been in the United States fewer than four years at the time of application. ... students maintain and further develop their native language skills by engaging in peer-mediated instructional activities using materials and textbooks in English as well as their native languages (http://www.ihsnyc.org/).

Rather than being organized according to traditional subject matter, the IHS curriculum is structured in an interdisciplinary way. Among the other instructional innovations pursued by educators at IHS are the following: portfolio rather than standardized test assessment, career education across the curriculum, collaborative peer-supported learning, close contacts and collaboration with the wider community, and a focus on language awareness and engaging students' multilingual repertoires across curricular tasks and projects (DeFazio, 1997). Students' home languages are integrated into all phases of learning and assessment. For example, in developing their portfolios in the various interdisciplinary programs, students write in both their L1 and English, according to their choice. Other students or members of the wider community assist in translating material that has been written in a language 
the teachers do not know. Among the specific instructional initiatives noted by De Fazio are the following:

- Students write an autobiography or a biography of another student using their choice of English, L1 or both languages.

- Students work in groups to carry out comparisons of English and their L1s including topics such as the sounds in different languages (using the International Phonetic Alphabet) and crosslinguistic differences in syntax and other aspects of the languages.

- Students write multilingual children's books on some aspect of language or linguistics (e.g., 'How the Chinese Got Language' or 'The Monster that Ate Polish Words').

- Students interview community members about social dimensions of language such as dialect, language prejudice, bilingual education, etc.

The academic outcomes of the instructional program at IHS are impressive. According to DeFazio (1997), entering students score in the lowest quartile on tests of English proficiency, yet more than 90 percent of them graduate within four years and move on to post-secondary education. DevTech Systems (1996) reported that the drop-out rate among English learners at IHS was only 3.9 percent compared to almost 30 percent in New York City as a whole. The success of the initial IHS has given rise to a network of almost 30 international schools in New York City and elsewhere in the United States that serve only English language learners.

Little and Kirwin (2018, 2019). Scoil Bhríde (Cailíní). Scoil Bhríde (Cailíní) (St. Bridget's School for Girls) is a primary school located in the western suburbs of Dublin, Ireland. In the school year 2014-2015, it had more than 300 pupils, almost 80 percent of whom spoke a language other than English at home. In total, 51 home languages were spoken by the pupils. Over a period of 20 years (1994-2014), the school principal, Déirdre Kirwin worked with school staff, and in collaboration with Trinity College Dublin professor David Little, to implement translanguaging pedagogies that would connect with pupils' lives and affirm their plurilingual identities. The school's pedagogical orientation was shaped by the following five principles: 
- An inclusive ethos: "effective schooling depends on being open to the experience and knowledge pupils bring with them" (2018, p. 317).

- An open language policy and integrated approach to language education: English is the major language of instruction throughout primary school, but Irish is taught and used informally by teachers in interaction with pupils from the two years of preschool (Junior and Senior Infants) through the six years of primary school. French is introduced in years 5 and 6 . Teachers encourage pupils to become conscious of connections between their home languages and these three languages. No restrictions are placed on pupils' use of their home languages inside or outside the classroom. According to Little and Kirwin (2018, p. 321), "Pupils are engaged with language, its uses and varieties throughout the school. They welcome new pupils because they bring new languages with them...".

- A strong emphasis on the development of literacy skills: Literacy development is encouraged in pupils' home languages as well as English, Irish, and French. "Not only are [home languages] visible throughout the school, from Junior Infants to Sixth Class, in classroom and corridor displays; they are also used to support the development of pupils' English language skills" (2018, p. 323).

- Teaching methods that strive to be as explicit as possible: Teachers promote a reflective approach to learning that encourages self-awareness and self-assessment among pupils.

- Respect for teachers' professional autonomy: Teachers are expected to comply with the school's inclusive ethos and its open language policy, and to emphasize literacy engagement and explicit teaching methods. However, they have wide latitude in how they implement these policies and their professional judgment and autonomy is respected within the school community.

Little and Kirwin $(2018,2019)$ document multiple examples of how these pedagogical principles were put into practice at Scoil Bhríde. They also document the enthusiasm of both teachers and pupils for the multilingual pedagogical approach implemented in the school. Despite the large immigrantbackground school population coming from primarily lower socioeconomic backgrounds, the school's standardized test scores in English and mathematics 
(administered every year between First and Sixth Class) have consistently been at or above the national average. This contrasts with the significant underachievement in most European countries of first- and second-generation immigrant pupils, particularly when they are clustered in schools with large concentrations (more than 25 percent) of pupils from similar immigrant backgrounds (OECD, 2015).

Little and Kirwin (2019) conclude that encouraging immigrantbackground learners to use their home languages inside and outside the school promotes cross-linguistic comparisons and the development of language awareness, both of which contribute to pupils' educational success. This approach stimulates pupils to transfer skills and knowledge from school languages to home languages (and vice-versa) and supports parents in developing their children's home language literacy skills.

\section{Conclusion}

Although momentum to implement pedagogies to sustain the multilingualism that immigrant-background students bring to school has grown significantly in recent years, inspirational examples such as those discussed above still represent only a small fraction of pedagogical reality. Most schools still continue to undermine students' multilingualism either through benign neglect or sometimes explicit prohibition on the use of students' home languages within the public space of the school. There is a large degree of research consensus regarding the theoretical and empirical legitimacy of multilingual pedagogical approaches, but this research consensus is silenced in many contexts by the ideological distaste for genuine intercultural inclusion and effective language education.

Reflecting on the lack of broader policy uptake in the Irish context, Little and Kirwin (2018) conclude their account of Scoil Bhríde's inspirational pedagogy on a pessimistic note, suggesting that "the impact of its highly successful policy and practice is minimal" (p. 337). I am somewhat more optimistic that the momentum for evidence-based multilingual instructional approaches is real and will continue to increase. Hopefully, it will reach a tipping point in at least some educational contexts whereby the linguistic 
resources that immigrant-background students bring to school will be recognized and affirmed.

\section{References}

Agirdag, O. (2010). Exploring bilingualism in a monolingual school system: Insights from Turkish and native students from Belgian schools. British Journal of Sociology of Education, 31(3), 307-321. doi: $10.1080 / 01425691003700540$

Agirdag, O., \& Vanlaar, G. (2016). Does more exposure to the language of instruction lead to higher academic achievement? A cross-national examination. International Journal of Bilingualism, 22(1), 123-137. doi: $10.1177 / 1367006916658711$.

Auger, N. (2008). Comparing our languages (a tool for maintaining individual multilingualism). Synergies sud-est européen, 1, 93-99. Retrieved from http://gerflint.fr/Base/SE-europe/auger.pdf.

Celic, C. \& Seltzer, K. (2011). Translanguaging: A CUNY-NYSIEB guide for educators. New York, NY: CUNY-NYSIEB. Retrieved from http://www.nysieb.ws.gc.cuny.edu/files/2012/06/FINALTranslanguaging-Guide-With-Cover-1.pdf.

Chumak-Horbatsch, R. (2012). Linguistically appropriate practice: A guide for working with young immigrant children. Toronto: University of Toronto Press.

Chumak-Horbatsch, R. (Ed.), (2019). Using linguistically appropriate practice: A guide for teaching in multilingual classrooms. Bristol: Multilingual Matters.

Christensen, G., \& Stanat, P. (2007, September). Language policies and practices for helping immigrant second-generation students succeed. The Transatlantic Task Force on Immigration and Integration convened by the Migration Policy Institute and Bertlesmann Stiftung. Retrieved from https://www.migrationpolicy.org/research/language-policiesand-practices-helping-immigrants-and-second-generation-studentssucceed.

Cook, V. (1995). Multi-competence and learning of many languages. Language, Culture and Curriculum, 8, 93-98. 
Cook, V. (2007). The goals of ELT: Reproducing native-speakers or promoting multicompetence among second language users? In J. Cummins and C. Davison (Eds.), International handbook of English language education. Volume 1 (pp. 237-248). Norwell, MA: Springer.

Cummins, J. (1979). Linguistic interdependence and the educational development of bilingual children. Review of Educational Research, 49, 222-251.

Cummins, J. (1981). The role of primary language development in promoting educational success for language minority students. In California State Department of Education (ed.), Schooling and language minority students: A theoretical framework (pp. 3-49). Los Angeles: Evaluation, Dissemination and Assessment Center, California State University.

Cummins, J. (1999). Alternative paradigms in bilingual education research: Does theory have a place? Educational Researcher, 28(7), 26-41.

Cummins, J. (2001). Negotiating identities: Education for empowerment in a diverse society ( $2^{\text {nd }}$ ed.). Los Angeles: California Association for Bilingual Education.

Cummins, J. (2007). Rethinking monolingual instructional strategies in multilingual classrooms. The Canadian Journal of Applied Linguistics, $10,221-240$.

Cummins, J. (2009). Transformative multiliteracies pedagogy: School-based strategies for closing the achievement gap. Multiple Voices for Ethnically Diverse Exceptional Learners, 11, 38-56.

Cummins, J. (2017). Teaching minoritized students: Are additive approaches legitimate? Harvard Education Review, 87(3), 404-425.

Cummins, J. (2018). Urban multilingualism and educational achievement: Identifying and implementing evidence-based strategies for school improvement. In P. Van Avermaet, S. Slembrouck, K. Van Gorp, S. Sierens, \& K. Maryns (Eds.) The multilingual edge of education (pp. 67-90). London: Palgrave Macmillan.

Cummins, J., \& Early, M. (Eds.), Identity texts: The collaborative creation of power in multilingual schools. Stoke-on-Trent, England: Trentham Books.

DeFazio, A. J. (1997). Language awareness at The International High School. In L. Van Lier and D. Corson (Eds.), Knowledge about language. 
Encyclopedia of Language and Education (pp. 99-107). Dordrecht, The Netherlands: Kluwer Academic Publishers, Inc.

DevTech Systems Inc. (1996). A descriptive study of the ESEA Title VII educational services provided for secondary school limited English proficient students: Final report. Washington, DC: National Clearinghouse for Bilingual Education.

Edele, A., \& Stanat, P. (2016). The role of first-language listening comprehension in second-language reading comprehension. Journal of Educational Psychology, 108(2), 163-180.

Esser, H. (2006). Migration, language, and integration. AKI Research Review 4. Berlin: Programme on Intercultural Conflicts and Societal Integration (AKI), Social Science Research Center. Retrieved from https://wzb.eu/www2000/alt/aki/files/aki_research_review_4.pdf.

Flores, N., \& Rosa, J. (2015). Undoing appropriateness: Raciolinguistic ideologies and language diversity in education. Harvard Educational Review, 85, 149-171.

Francis, D., Lesaux, N., \& August, D. (2006). Language of instruction. In D. August \& T. Shanahan (Eds.), Developing literacy in secondlanguage learners. Report of the National Literacy Panel on LanguageMinority Children and Youth. (pp. 365-413). Mahwah, NJ: Lawrence Erlbaum Associates Publishers.

García, O. (2009). Bilingual education in the $21^{\text {st }}$ century. A global perspective. Boston: Basil Blackwell.

García, O. \& Kleyn, T. (Eds.), (2016). Translanguaging with multilingual students: Learning from classroom moments. New York: Routledge.

García, O., \& Wei, L. (2014). Translanguaging: Language, bilingualism and education. New York: Palgrave Macmillan.

Hélot, C., \& Young, A. (2006). Imagining multilingual education in France: A language and cultural awareness project at primary level. In O. García, T. Skutnabb-Kangas, \& M. T. Torres-Guzmán, (Eds.), Imagining multilingual schools: Languages in education and glocalization (pp. 69-90). Clevedon, England: Multilingual Matters.

Herdina, P. \& Jessner. U. (2002). A dynamic model of multilingualism: Changing the psycholinguistic perspective. Clevedon, UK: Multilingual Matters. 
Kapoyannis, T. (2019). Literacy engagement in multilingual and multicultural learning spaces. TESL Canada Journal, 36(2), 1-25. doi: 10.18806/tesl.v36i2.1298.

Little, D. \& Kirwin, D. (2018). Translanguaging as a key to educational success: The experience of one Irish primary school. In P. Van Avermaet, S. Slembrouck, K. Van Gorp, S. Sierens, \& K. Maryns (Eds.), The multilingual edge of education (pp. 313-339). London: Palgrave Macmillan.

Little, D. \& Kirwin, D. (2019). Engaging with linguistic diversity. London: Bloomsbury Academic.

Mary, L. \& Young, A. S. (2017). From silencing to translanguaging: Turning the tide to support emergent bilinguals in transition from home to preschool. In B. Paulsrud, J. Rosen, B. Straszer, \& A. Wedin (Eds.), New perspectives on translanguaging and education (pp. 108-128). Bristol: Multilingual Matters.

Messick, S. (1987). Validity. Research Report, RR-87-90. Princeton, NJ: Educational Testing Service.

National Academies of Sciences, Engineering, and Medicine. (2017). Promoting the Educational Success of Children and Youth Learning English: Promising Futures. Washington, DC: The National Academies Press. doi: $10.17226 / 24677$.

Nusche, D. (2009). What works in migrant education? A review of evidence and policy options. OECD Education Working Papers, No. 22, OECD Publishing. doi: $10.1787 / 227131784531$.

OECD. (2012). Untapped skills: Realising the potential of immigrant students. Paris: OECD.

OECD (2015). Helping immigrant students succeed at school - and beyond. OECD, Paris. Retrieved from https://www.oecd.org/education/Helpingimmigrant-students-to-succeed-at-school-and-beyond.pdf.

Pickel, T., \& Hélot, C. (2014). 'Because it is my life, and I'm the one who makes choices'. Newcomers in the French education system and career guidance: What about their plurilingual competence? In P. Grommes \& A. $\mathrm{Hu}$ (Eds.), Plurilingual education: Policies - practice - language development (pp. 161-117). Hamburg: Hamburg Studies in Linguistic Diversity: John Benjamins. 
Porter, R. P. (1990). Forked tongue: The politics of bilingual education. New York, NY: Basic Books.

Prasad, G. (2016). Beyond the mirror towards a plurilingual prism: Exploring the creation of plurilingual "identity texts" in English and French classrooms in Toronto and Montpellier. Intercultural Education, 26(6), 497-514. Special Issue ed. A. Gagné \& C. Schmidt. doi: 10.1080/14675986.2015.1109775.

Pulinx, R., Van Avermaet, P., \& Agirdag, O. (2016) Silencing linguistic diversity: The extent, the determinants, and consequences of the monolingual beliefs of Flemish teachers. International Journal of Bilingual Education and Bilingualism, 20(5), 542-556. doi: 10.1080/13670050.2015.1102860.

Ravitch, D. (2013). Reign of error: The hoax of the privatization movement and the danger to America's public schools. New York, NY: Alfred A. Knopf.

Rossell, C. H., \& Baker, K. (1996). The effectiveness of bilingual education. Research in the Teaching of English, 30, 7-74.

Rossell, C. H., \& Kuder, J. (2005). Meta-Murky: A rebuttal to recent metaanalyses of bilingual education. In J. Söhn (Ed.), The effectiveness of bilingual school programs for immigrant children. AKI Research Review 2 (pp. 43-76). Berlin: Programme on Intercultural Conflicts and Societal Integration (AKI), Social Science Research Center. Retrieved from http://www.ssoar.info/ssoar/handle/document/11029. Schlesinger, A. J. (1991). The disuniting of America. New York: W.W. Norton. Scheele, A. F., Leseman, P., \& Mayo, A. Y. (2010). The home language environment of monolingual and bilingual children and their language proficiency. Applied Psycholinguistics, 31, 117-140. doi: 10.1017/S0142716409990191.

Stanat, P., \& Christensen, G. (2006). Where immigrant students succeed: A comparative review of performance and engagement in PISA 2003. Paris: OECD.

Truth and Reconciliation Commission of Canada. (2015). Canada's residential schools: The history, Part 1 Origins to 1939. The Final Report of the Truth and Reconciliation Commission of Canada, Volume 1. 
Retrieved from http://nctr.ca/assets/reports/Final\%20Reports/

Volume_1_History_Part_1_English_Web.pdf.

\section{Jim Cummins}

Toronto universitetas, Kanada

jcummins320@gmail.com

\section{MOKYKLOS DAUGIAKALBYSTĘ TURĖTU SLOPINTI AR STIPRINTI? TEORIJOS, TYRIMU IR PEDAGOGINĖS PRAKTIKOS ANALIZE்}

Santrauka. Daugelis mokyklu pasaulyje teikia prioriteta kalbu mokymui ir siekia vystyti savo moksleiviu dvikalbystès bei daugiakalbystès gebejjimus. Tačiau, gana dažnuose kontekstuose, mokyklos taip pat sistematiškai ir sąmoningai slopina marginalizuotu moksleiviu iš imigrantu šeimu potenciala vystyti daugiakalbystès gebèjimus. Šis daugiakalbystès slopinimas vykdomas arba atvirai uždraudžiant moksleiviams vartoti savo gimtasias kalbas (L1) mokykloje arba ignoruojant kalbas, kurias moksleiviai atsineša i mokykla (nepiktybinis aplaidumas). Kai kuriais atvejais moksleiviu L1 atskirtis yra racionalizuojamas remiantis tuo, jog L1 palaikymas kliudo moksleiviams integruotis i plačiaja visuomenę. Kitais atvejais atskirtis paremta jsitikinimu, jog tarp kalbu vyksta konkuravimas, o L1 vartojimas mokykloje arba namuose sumažins moksleiviu salyti su mokyklos kalba (L2). Šio "užimtumo laiko" (angl. time-on-task) argumento pagristumas yra kritiškai išanalizuojamas šiame darbe. Aš argumentuoju, jog tyrimai neparode jokio nuoseklaus ryšio tarp imigrantu moksleiviu akademiniu pasiekimy (vartojant L2) ir L1 vartojimo namuose arba mokykloje. Priešingai, keletas tyrimu sinteziu atskleidè teigiamus dvikalbiu programu, skirtu marginalizuotiems moksleiviams, akademinius rezultatus bei daugiakalbiu arba transkalbiu pedagogiku igyvendinimo iprastoje klasėje tinkamumą.

Pagrindinès sąvokos: dvikalbis švietimas; cross-lingual transfer; namuose vartojama kalba; vaikai iš imigrantu šeimu; tarpusavio priklausomumas; daugiakalbystė; užimtumo laikas; transkalbystè. 